\title{
Beetroot Juice and Red Spinach Juice to Increase Hemoglobin Levels in Anemic Adolescent Girls
}

Rudolf Boyke Purba ${ }^{1 *}$, Olga Lieke Paruntu ${ }^{1}$, Irza Nanda Ranti ${ }^{1}$, Vera Harikedua ${ }^{1}$, Grace Langi ${ }^{1}$, Jufri Sineke ${ }^{1}$, Joice Mermy Laoh ${ }^{2}$, Ellen Pesak ${ }^{2}$, Yohanis Tomastola ${ }^{1}$, Daniel Robert ${ }^{1}$, Salman Salman ${ }^{3}$

${ }^{1}$ Department of Nutrition, Politeknik Kesehatan Kementerian Kesehatan, Manado, Indonesia; ${ }^{2}$ Department of Nursing, Politeknik Kesehatan Kementerian Kesehatan, Manado, Indonesia; ${ }^{3}$ Department of Nutrition, Politeknik Kesehatan Kementerian Kesehatan, Gorontalo, Indonesia

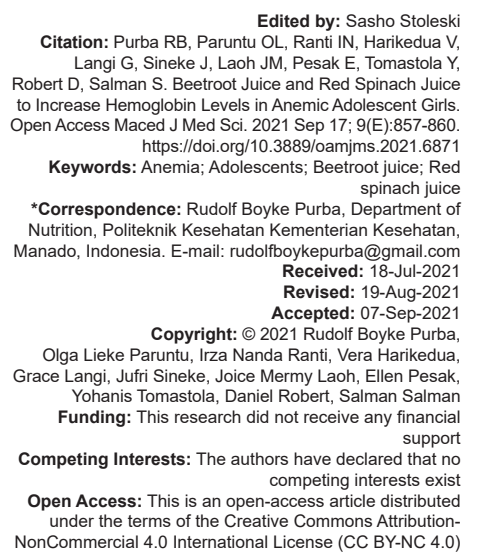

\section{Abstract}

BACKGROUND: The problem of iron (Fe) deficiency anemia in adolescents often occurs due to incorrect food habits caused an imbalance in nutritional intake and the recommended dietary adequacy. Spinach and beetroot are alternative plants to meet the Fe needs of anemic adolescents. The content of Vitamin C or ascorbic acid in beets and spinach can help absorb Fe in the body. Beetroot also contains relatively sufficient Fe beneficial in overcoming anemia caused by Fe deficiency.

AIM: This study aimed to determine the effect of beetroot juice and red spinach juice on increasing hemoglobin $(\mathrm{Hb})$ levels in anemic adolescents.

METHODS: It was a Quasi Experiment with a pretest-posttest, non-equivalent control group design. The research subjects were twenty people per group of anemic adolescent girls.

RESULTS: In this study, after 2 weeks of beetroot juice intervention to anemic adolescent girls, there was an increase in $\mathrm{Hb}$ levels from $11.47 \mathrm{~g} / \mathrm{dl}$ to $12.02 \mathrm{~g} / \mathrm{dl}$. The increase in $\mathrm{Hb}$ levels was statistically different (Paired t-test) $(p<0.05)$. However, the 2 weeks of red spinach juice intervention also experienced an increase in $\mathrm{Hb}$ levels, from $11.4 \mathrm{~g} / \mathrm{dl}$ to $12.08 \mathrm{~g} / \mathrm{dl}$. The increase in $\mathrm{Hb}$ levels was statistically significant $(\mathrm{p}<0.05)$

CONCLUSION: An effect of beetroot juice and red spinach juice consumption on $\mathrm{Hb}$ levels of anemic adolescent girls.

\section{Introduction}

Anemia is one of the nutritional problems in Indonesia. Based on Basic Health Research (in Indonesian is Riset Kesehatan Dasar, abbreviated as RISKESDAS) in 2013, the prevalence of anemia in Indonesia was $21.7 \%$, anemic aged $5-14$ years was $26.4 \%$, and aged $15-24$ years was $18.4 \%$, it was tended to increase in the elderly [1]. Anemia in North Sulawesi is lower when compared to other provinces in Indonesia, about $8.7 \%$ in women.

Adolescents are risky to anemia due to their period of growth, so they need more micronutrients and macronutrients. The problem of nutritional anemia in adolescents often occurs due to incorrect food habits causes an imbalance in nutritional intake with the Recommended Dietary Adequacy [2]. The iron (Fe) supplementation program for anemic adolescents in Bogor has not been running effectively [3].

Research on anemic adolescent girls in Kudus resulted in red spinach on hemoglobin $(\mathrm{Hb})$ levels [4].
Likewise, the research in Kediri on anemic pregnant women shows an improvement in $\mathrm{Hb}$ levels after obtaining spinach juice. One food that may increase $\mathrm{Hb}$ levels in the blood is spinach stew [5]. Spinach is one of the alternative plants to fulfill the Fe needs of adolescents with anemia. Furthermore, one of the natural food ingredients that can overcome anemia is beetroot [6]. This beet fruit is classified as a functional food due to its good impact on health. This food ingredient is often used as a natural dye in various types of processed food because of its unique purple or purplish color [7]. Apart from being a colorant, beetroot can also be consumed raw or processed into drinks such as juice. Some of the benefits of beetroot juice are lowering blood pressure, increasing the amount of oxygen, improving stamina, preventing congenital disabilities, and overcoming menstrual problems [8]. The active substance contained in red spinach and beets that can increase $\mathrm{Hb}$ is Fe. In $100 \mathrm{~g}$ of red spinach contains $7.0 \mathrm{mg}$ of Fe and $62 \mathrm{mg}$ of Vitamin C. The role of Vitamin $\mathrm{C}$ is to help the absorption of non-heme Fe. Likewise with beetroot which contains $1.0 \mathrm{mg}$ of $\mathrm{Fe}$ and $10 \mathrm{mg}$ of Vitamin C [9]. 
A very well-known benefit of this beet is to overcome anemia, or even known as anti-anemia. A study was conducted on adolescent girls in India who suffered from anemia, whether mild, moderate, or severe [8]. The content of Vitamin $\mathrm{C}$ or ascorbic acid in this beet can help absorb Fe in the body. This beet also contains relatively sufficient $\mathrm{Fe}$ to overcome anemia caused by Fe deficiency [10]. More attention should be paid to combining daily food, consisting of a mixture of Fe sources derived from animals and plants and other nutrients that can help absorption in the body.

This study aimed to determine the effect of beetroot juice and red spinach juice on $\mathrm{Hb}$ improvement in anemic adolescent girls.

\section{Methods}

\section{Design and sampling}

This was a Quasi Experiment with a pretestposttest, non-equivalent control group design, conducted in June - November 2020 in Manado, North Minahasa, and Bitung. The population was adolescent girls aged 14-19 years, suffered from anemia identified by $\mathrm{Hb}$ levels of $<12 \mathrm{~g} / \mathrm{dl}$. The number of samples used was 25 people per group of adolescent girls suffering from $\mathrm{Fe}$ deficiency anemia (met the inclusion and exclusion criteria). The sampling technique used was simple random sampling. Subject inclusion criteria were: (1) Anemic adolescent girls ( $\mathrm{Hb}$ level $<12 \mathrm{~g} / \mathrm{dl}$ ); (2) In good health can read and write; (3) Willing to participate in research. Subject exclusion criteria are teenage girls who are menstruating.

\section{Interventions and observations}

First, it was screening of anemic adolescent girls through examination of blood samples. The previous sample was willing to be a sample by signing the informed consent. Health professionals took blood samples from capillaries, and then, $\mathrm{Hb}$ was determined using Family $\mathrm{Dr}, \mathrm{Hb}<12 \mathrm{~g} / \mathrm{dl}$ would be identified anemic. Selected samples would be rechecked for $\mathrm{Hb}$ level after 2 weeks of consuming beetroot juice or red spinach juice.

Red spinach and beetroot used as main research materials were obtained from the market or supermarket. The juices were prepared in the following ways; red spinach leaves and beetroot were weighed and washed under running water, then drained. It was brewed with boiling water for about $5 \mathrm{~min}$, then mashed with a blender and filtered. Honey was added to the juice as a natural sweetener. Then, it was packaged in plastic cups and ready to be distributed to the respondent once a day every morning for 2 weeks. Hb level observations were conducted a day before (day 0) and a day after (day 15) after the intervention/treatment.

Respondents who were selected as research subjects were anemic adolescent girls ( $\mathrm{Hb}$ levels <12 $\mathrm{g} / \mathrm{dl}$ ) who met the research criteria. The respondents were divided into three groups by purposive sampling technique. The experimental Group I $(\mathrm{n}=25)$ received $150 \mathrm{ml}$ of beetroot juice, the experimental group $\mathrm{II}(\mathrm{n}=25)$ received $150 \mathrm{ml}$ of red spinach juice, and the control group $(n=25)$ did not receive any intervention. The $\mathrm{Hb}$ level of the sample was measured as a pretest (when selected as a sample, day 0) and post-test (day 15).

This research protocol was approved by the Health Polytechnic Ethics Committee of the Manado Health Ministry (No. KEPK.01/04/026/2020).

\section{Data analyses}

The data were analyzed by paired t-test, which was previously tested for normality of data distribution.

\section{Results}

The study results show that the average age of the beetroot juice group was 14-15 year (10 people). In the red spinach juice group, the average age of the sample was mainly in the 18-19 year age group (16 people). Meanwhile, in the control group, mostly at the age of $16-17$ years (10 people) (Table 1 ).

Table 1: Age characteristics by respondent group

\begin{tabular}{llll}
\hline Age group (years) & Respondent & & \\
\cline { 2 - 4 } & Beetroot juice group & Spinach juice group & Control \\
\hline $14-15$ & 10 & 3 & 8 \\
$16-17$ & 4 & 4 & 10 \\
$18-19$ & 6 & 16 & 2 \\
Total & 20 & 23 & 20 \\
\hline
\end{tabular}

\section{Beetroot juice and red spinach juice intervention on $\mathrm{Hb}$ levels}

After 2 weeks of intervention of beetroot juice to anemic adolescent girls, there was an increase in $\mathrm{Hb}$ levels from $11.47 \mathrm{~g} / \mathrm{dl}$ to $12.02 \mathrm{~g} / \mathrm{dl}$. The increase in $\mathrm{Hb}$ levels was statistically different (Paired t-test) ( $p$ $<0.05$ ). The 2 weeks intervention of red spinach juice also experienced an increase in $\mathrm{Hb}$ levels, from $11.4 \mathrm{~g} /$ $\mathrm{dl}$ to $12.08 \mathrm{~g} / \mathrm{dl}$. The improvement in $\mathrm{Hb}$ levels was statistically significant $(p<0.05)$ (Table 2$)$.

Table 2: Differences in average $\mathrm{Hb}$ levels (pre and post)

\begin{tabular}{lllllll}
\hline Intervention group & Pre-test & & Post-test & p-value \\
\cline { 2 - 3 } \cline { 3 - 5 } & Average $\mathrm{Hb}(\mathrm{gr} / \mathrm{dl})$ & $\mathrm{SD}$ & & Average $\mathrm{Hb}(\mathrm{gr} / \mathrm{dl})$ & $\mathrm{SD}$ & \\
\hline Beetroot juice & 11.47 & 0.661 & 12.02 & 0.583 & $0.000^{*}$ \\
Spinach juice group & 11.4 & 0.58 & 12.08 & 0.565 & $0.000^{*}$ \\
\hline Hb: Hemoglobin. & & & & &
\end{tabular}




\section{Differences in $\mathrm{Hb}$ levels of beetroot juice group and control group}

The intervention of beetroot juice to the $\mathrm{Hb}$ levels of anemic adolescent girls showed different results compared with the control group. After being tested statistically (independent t-test), it turned out that there was a significant difference $(p<0.05)$ (Table 3$)$.

Table 3: Differences in average $\mathrm{Hb}$ levels (pre and post) in the beetroot juice group with control

\begin{tabular}{|c|c|c|c|c|c|c|}
\hline \multirow{2}{*}{$\begin{array}{l}\text { Intervention } \\
\text { group }\end{array}$} & \multicolumn{3}{|l|}{ Pre-test } & \multicolumn{3}{|l|}{ Post-test } \\
\hline & Average $\mathrm{Hb}(\mathrm{gr} / \mathrm{dl})$ & SD & $p$-value & Average $\mathrm{Hb}(\mathrm{gr} / \mathrm{dl})$ & SD & $p$-value \\
\hline Beetroot Juice & 11.47 & 0.661 & 0.592 & 12.02 & 0.583 & $0.000^{*}$ \\
\hline Control & 11.31 & 0.481 & & 11.47 & 0.417 & \\
\hline
\end{tabular}

\section{Differences in $\mathrm{Hb}$ levels of red spinach juice and control group}

In the group of anemic adolescent girls who received and consumed red spinach juice, when compared to the $\mathrm{Hb}$ level with the control group, there was also a significant difference $(p<0.05)$ (Table 4).

Table 4: Differences in the mean $\mathrm{Hb}$ levels (pre and post) in the red spinach leaf juice group with control

\begin{tabular}{|c|c|c|c|c|c|c|}
\hline \multirow{2}{*}{$\begin{array}{l}\text { Intervention } \\
\text { group }\end{array}$} & \multicolumn{3}{|l|}{ Pre-Test } & \multicolumn{3}{|l|}{ Post-Test } \\
\hline & Average $\mathrm{Hb}(\mathrm{gr} / \mathrm{dl})$ & SD & $p$-value & Average $\mathrm{Hb}$ (gr/dl) & SD & p-value \\
\hline Spinach Juice & 11.40 & 0.587 & 0.592 & 12.08 & 0.565 & $0.000^{*}$ \\
\hline Group & & & & & & \\
\hline Control & 11.31 & 0.481 & & 11.47 & 0.417 & \\
\hline
\end{tabular}

\section{Discussion}

Giving beetroot juice can accelerate $\mathrm{Hb}$ levels in anemic adolescent girls because beetroot has a high Fe content that can regenerate and reactivate red blood cells and bring fresh oxygen to the body. Beetroot (in $100 \mathrm{~g}$ ) contains Vitamin C, Vitamin B, and $0.80 \mathrm{mg}$ $\mathrm{Fe}$, equivalent to $10 \%$ of the total daily $\mathrm{Fe}$ requirement. $A$ very well-known benefit of this beet is to overcome anemia, or even known as anti-anemia. A study was conducted on adolescent girls in India who suffered from anemia, either mild, moderate, or severe. There is an effect of consumption of red spinach juice on the increase in hemoglobin levels in pregnant women in the second trimester [11]. The teenager was given one glass of beetroot juice for 20 days in the morning. The results showed that the average $\mathrm{Hb}$ level of the adolescents increased significantly [12].

This study indicates that giving beet juice to be consumed by anemic adolescent girls as much as 150 cc every day for 2 weeks can increase their $\mathrm{Hb}$ levels. Initially, the average $\mathrm{Hb}$ level was $11.47 \mathrm{~g} / \mathrm{dl}$ and increased to an average of $12.02 \mathrm{~g} / \mathrm{dl}$. Statistically, there was a significant effect of giving beetroot juice on the increase in $\mathrm{Hb}$ levels of anemic adolescent girls $(p<0.05)$.
Other research shows that minimum $\mathrm{Hb}$ increase before and after the administration of Fe and beetroot juice to pregnant women was $17.7 \mathrm{gr} \%$ and the maximum $\mathrm{Hb}$ level was $0.8 \mathrm{gr} \%$ [13]. The result of a study by Suryandari and Happinasari (2015) and Wenda (2017) in the working area of Public Health Center, Pekanbaru, Indonesia, showed that the administration of beetroot juice was effective for $\mathrm{Hb}$ levels in pregnant women with anemia [14]. This study also follows a similar study from Al-Aboud (2018), which found an increase in $\mathrm{Hb}$ levels in women after consuming beetroot for 20 days [15]. Likewise, girl soccer players who were given beetroot juice for 6 weeks showed a significant increase in $\mathrm{Hb}$, Hematocrit, Fe, and ferritin levels $(p<0.05)$ [16]. The study of Chauhan et al. (2017) also revealed a significant increase in $\mathrm{Hb}$ levels after consuming beets for 30 days $(p<0.001)$ [17].

Spinach leaves contain high $\mathrm{Fe}$ to prevent anemia. The Fe content in spinach leaves can be useful for the process of forming $\mathrm{Hb}$ in the blood. If one can consume spinach leaves, a person will have blood $\mathrm{Hb}$ levels within normal limits and prevent anemia [18]. Spinach leaf is a vegetable food ingredient that contains the highest $\mathrm{Fe}$, which is $3.9 \mathrm{mg} / 100 \mathrm{~g}$ compared to other types of vegetables, such as mustard greens of 2.9 mg, katuk leaves of $2.7 \mathrm{mg}$, kale of $2.5 \mathrm{mg}$, and cassava leaves of $2.0 \mathrm{mg}$ [19].

The same result was also found by Kusumawati (2019), consumption of lime-spinach juice has a significant effect on $\mathrm{Hb}$ levels of anemic adolescent girls in a public senior high school (SMAN 5) in Kediri [20]. Besides, Suhada et al. (2019) revealed a significant effect of spinach on changes in $\mathrm{Hb}$ levels of adolescent girls at a junior high school (SMP 3) in Kalasan Sleman [21]. Red spinach juice also significantly increases pregnant women's $\mathrm{Hb}$ levels in the second trimester [22].

Food intake other than giving spinach is by consuming Moringa leaf extract which can increase $\mathrm{Hb}$ levels of adolescent girls and pregnant women. Consumption of tempeh and anchovies can also increase $\mathrm{Hb}$ in anemic pregnant women [23]. Consumption of Moringa leaf tea bags can also increase $\mathrm{Hb}$ in adolescent girls [24].

\section{Conclusion}

There was an effect of beetroot juice and red spinach juice on $\mathrm{Hb}$ improvement in anemic adolescents. Adolescent girls who are anemic may consume beetroot juice and or red spinach juice as an alternative food for therapy of $\mathrm{Hb}$ improvement and prevent anemia. 


\section{References}

1. Kemenkes RI. Riset Kesehatan Dasar (RISKESDAS). Indonesia: Balitbang Kemenkes RI; 2013. https://doi.org/10.32922/jkp.v8i2

2. Nicholaus C, Martin HD, Kassim N, Matemu AO, Kimiywe J. Dietary practices, nutrient adequacy, and nutrition status among adolescents in boarding high schools in the kilimanjaro region, Tanzania. J Nutr Metab. 2020;2020:3592813. https://doi. org/10.1155/2020/3592813

PMid:32685204

3. Permatasari T, Briawan D, Madanijah S. Effectiveness of iron supplementation programme in adolescent girl at Bogor city. Med Kesehatan Masyarakat Indones. 2018;14(1):1-8.

4. Kudus SM, Faridah U, Ayuningrum R. Red Spinach To Increase Hemoglobin Level for Adolescents On Class XII SMK Al-Islam Kudus. J SMART Keperawatan Sekolah Tinggi IImu Kesehatan (STIKes) Karya Husada. 2017;4(1):90-6. https://doi. org/10.34310/jskp.v4i1.102

5. Dewi SS, Panjaitan MN, Ramadhini D. The Effect of Red Spinach Stew on Increasing Hemoglobin Levels of Pregnant Women in Losung Village, South Padangsidimpuan District, Padangsidimpuan City in 2020. Indones Health Sci J. 2021;6(1):80-6. https://doi.org/10.35451/jkg.v3i2.663

6. Kadhem WM, Enaya $\mathrm{H}$, Kadhom AS. The role of Beta vulgaris (beetroot) in hemoglobin $(\mathrm{Hb})$ elevating in patients with Anemia due to iron deficiency. Al-Qadisiyah J Vet Med Sci. 2018;17(2):139-42. https://doi.org/10.29079/vol17iss2art518

7. Damiati, Suriani M. Development of bit fruit extract (beetroot) as a natural color for tempe noodle products. J Phys Conf Ser. 2021;1810(1):012077. https://doi. org/10.1088/1742-6596/1810/1/012077

8. Priya NG, Malarvizhi M, Jothi AJ. Beet root juice on haemoglobin among adolescent girls. IOSR J Nurs Health Sci. 2013;2(1):9-13.

9. Kemenkes RI. Tabel Komposisi Pangan Indonesia. Jakarta: Direktorat Jenderal Kesehatan Masyarakat, Kemenkes Rl; 2018. https://doi.org/10.32922/jkp.v8i2

10. Putri MC, Tjiptaningrum A, Kedokteran F, Lampung U, Klinik BP, Kedokteran $\mathrm{F}$, et al. Antianemic effect of beetroot (Beta vulgaris L.). Med J Lampung Univ. 2016;5(4);96-100.

11. Astuti EW, Widhi KH, Sugit AH. Pengaruh Konsumsi Jus Bayam Merah Terhadap Peningkatan Kadar $\mathrm{Hb}$ Pada lbu Hamil di Kecamatan Tawamangu; 2015. p. 72-9. https://doi. org/10.37160/arimbi.v1i1.583

12. Priya G, Malarvizhi M, Jothi AJ. Beet root juice on haemoglobin among adolescent girls. IOSR J Nurs Health Sci. 2013;2(1):9-13.

13. Wulandari RC, Susiloningtyas I. Betroot (Beta vulgaris) administration to anemic pregnant women for increasing hemoglobin level. Majalah Obstet Ginekol. 2020;28(3):109-12. https://doi.org/10.20473/mog.v28i32020.109-112

14. Suryandari $A E$, Happinasari $O$. Comparison of the increase in $\mathrm{Hb}$ levels in pregnant women who were given $\mathrm{Fe}$ with $\mathrm{Fe}$ of beets. Bhamada: Jurnal IImu dan Teknologi Kesehatan (E-Journal). 2014;5(2):9. https://doi.org/10.14710/jnc.v2i3.3441

15. Al-Aboud NM. Effect of red beetroot (Beta vulgaris L.) intake on the level of some hematological tests in a group of female volunteers. ISABB J Food Agric Sci. 2018;8(2):10-7. https://doi. org/10.5897/isabb-jfas2017.0070

16. Lotfi M, Azizi M, Tahmasbi W, Bashiri P. The effects of consuming 6 weeks of beetroot juice Beta vulgaris L. on hematological parameters in female soccer players. J Kermanshah Univ Med Sci. 2018;22(3):1-5. https://doi.org/10.5812/jkums.82300

17. Chauhan S, Gopani T, Suhagia B, Gupta S, Patel K, Patel M. Clinical evaluation of beet root and prickly pear in the management of anemia: An observational study. JAMS. 2018;2(4):274-7. https://doi.org/10.5530/jams.2017.2.30

18. Adriani M, Wirjatmadi B. Pengantar Gizi Masyarakat. Jakarta: Kencana Prenada Media Group; 2014.

19. Marmi. Gizi Dalam Kesehatan Reproduksi. Yogyakarta: Pustaka Pelajar; 2013.

20. Kusumawati LS. The Effect of Lime Water Spinach Juice Consumption on Hemoglobin Levels of Adolescent Girls with Anemia at SMAN 5 Kediri City. Java Health J. 2020;6(2):70-5. https://doi.org/10.37413/jmakia.v5i1.34

21. Suhada RI, Fitriani A, Widiany FL. The Effectiveness of Spinach on Changes in Hemoglobin Levels of Young Girls at SMP 3 Kalasan, Sleman, Yogyakarta. J Pangan Gizi. 2019;9(1):16-26. https://doi.org/10.26714/jpg.9.1.2019.16-26

22. Nasution RS, Aisyah S, Harahap HP. Consumption of Red Spinach Juice Can Increase Hemoglobin Levels in Second Trimester Pregnant Women. JKM. 2021;7(2):215-21. https://doi. org/10.33024/jkm.v7i2.3420

23. Diah D, Kristianto $Y$, Rullyni NT, Ridayani R, Rahmadona R. The Effect of Tempe Bilis Brains on Hemoglobin $(\mathrm{Hb})$ Levels of Pregnant Women with Anemia. QJK. 2019;13(2):54-61. https:// doi.org/10.36082/qjk.v13i2.86

24. Fauziandari EN. The Effectiveness of Moringa Leaf Extract on Increased Hemoglobin Levels in Adolescent Girls. J Kesehatan Karya Husada. 2019;7(2):185-90. https://doi.org/10.36577/jkkh. v7i2.230 